\title{
NOTES ON ORDOVICIAN CORRELATION CHARTS OF THE USSR PART OF THE EAST-EUROPEAN PLATFORM
}

Formal correlation charts of different systems and regions have been compiled in the USSR systematically from the late 50 s up to the date. Such correlation charts are compiled in accordance with special official rules issued in 1958 (Инструкция ..., 1958) and subsequently as an appendix of the USSR Stratigraphic Code of 1976 (text in English printed in 1979 , p. 131-139). The charts are to be discussed on and adopted by an interdepartmental regional stratigraphic conference and approved by the USSR Stratigraphic Committee. The design of the USSR correlation charts is similar to the internationally used ones. They are provided with explanatory notes, too.

As for the Ordovician System of the East-European Platform the following three official correlation charts are the most important ones.

1) The East-European (Russian) Platform chart compiled in 1962 and published in 1965 (Решения ..., 1965). In this chart 14 Ordovician regional stages («horizons») have been distinguished and a correlation of 8 local sections given. The chart was compiled mainly by Leningrad stratigraphers (T. Alikhova and others) and it was not fully accepted by the East Baltic geologists.

2) The East Baltic chart of 1976 (published in 1978) (Решения..., 1978). The chart was put together as a team work by Estonian, Latvian and Lithuanian stratigraphers and for the first time 18 regional stages with modern names (see Мянниль, 1966) were accepted and officially approved by the Stratigraphic Committee. The right-hand side of the chart consists of three columns reflecting main facial areas (confacies belts) with their different formal local stratigraphy - the North Estonian outcrop area, the West Latvian (= a part of the Central Confacies Belt of Baltoscandia by Jaanusson, 1976) and the south-eastern Lithuanian subsurface.

3) The East-European Platform chart compiled in 1984 and published recently (Решения ..., 1987). More than 20 authors took part in the compilation of this chart and the corresponding stratigraphic conference was held in Tallinn. The chart 1984 essentially differs from the previous platform chart (1962) in degree of refinement and amount of stratigraphic information involved.

In the following a short review of the platform chart 1984 is given.

The general standard subdivisions of the Ordovician System given in the left-hand side of the chart are those accepted in the USSR: the threefold division of the system into Lower, Middle and Upper Ordovician with boundaries of the middle subdivision at the bases of the «bifidus» and linearis zones; the British series with arbitrary boundaries coinciding in all cases with graptolite zonal limits (the lower boundary of Caradoc drawn at the base of the multidens Zone, that of Ashgill at the base of the linearis Zone). 
Ordovician regional subdivisions of the East-European Platform accepted in the correlation chart of 1984 , and their correlation with British standard units

\begin{tabular}{|c|c|c|c|c|}
\hline \multicolumn{3}{|c|}{ East-European Platform regional units } & \multicolumn{2}{|c|}{ British standard units } \\
\hline Series & \multicolumn{2}{|c|}{ Stages, substages } & Graptolite zones & Series \\
\hline \multirow{5}{*}{$\begin{array}{l}\text { Harju } \\
\text { (Upper Ordovician) }\end{array}$} & Porkuni $F_{11}$ & & $\begin{array}{l}\text { persculptus } \\
\text { extraordinarius }\end{array}$ & \multirow{4}{*}{ Ashgill } \\
\hline & \multirow{2}{*}{ Pirgu $F_{1 c}$} & \multirow{2}{*}{$\begin{array}{l}\mathrm{U} \\
\mathrm{L}\end{array}$} & anceps & \\
\hline & & & complanatus & \\
\hline & \multicolumn{2}{|l|}{ Vormsi $F_{1 b}$} & \multirow{2}{*}{ linearis } & \\
\hline & Nabala $F_{1 a}$ & $\begin{array}{l}\mathrm{U} \\
\mathrm{L}\end{array}$ & & \multirow{7}{*}{ Caradoc } \\
\hline \multirow{9}{*}{$\begin{array}{l}\text { Viru } \\
\text { (Middle Ordovician) }\end{array}$} & Rakvere E & & \multirow{2}{*}{ clingani } & \\
\hline & Oandu $D_{111}$ & & & \\
\hline & \multicolumn{2}{|l|}{ Keila $D_{11}$} & \multirow{3}{*}{ multidens } & \\
\hline & \multicolumn{2}{|l|}{ Jõhvi $D_{1}$} & & \\
\hline & \multicolumn{2}{|c|}{$\begin{array}{ll}\text { Idavere } \mathrm{C}_{\mathrm{HI}} & \mathrm{U} \\
\mathrm{L}\end{array}$} & & \\
\hline & \multicolumn{2}{|l|}{ Kukruse $C_{I I}$} & gracilis & \\
\hline & Uhaku $\mathrm{C}_{\mathrm{Ic}}$ & $\begin{array}{l}\mathrm{U} \\
\mathrm{L}\end{array}$ & teretiusculus & ? \\
\hline & \multicolumn{2}{|c|}{ Lasnamägi $\mathrm{C}_{\mathrm{Ib}}$} & \multirow{2}{*}{ murchisoni } & \multirow{3}{*}{ Llanvirn } \\
\hline & Aseri $\mathrm{C}_{1 \mathrm{a}}$ & & & \\
\hline \multirow{6}{*}{$\begin{array}{l}\text { Oeland } \\
\text { (Lower Ordovician) }\end{array}$} & Kunda $\mathrm{B}_{\mathrm{HI}}$ & $\mathrm{U}$ & artus & \\
\hline & Volkhov $\mathrm{B}_{\mathrm{II}}$ & $\begin{array}{l}\mathrm{U} \\
\mathrm{M} \\
\mathrm{L}\end{array}$ & hirundo & \multirow[t]{3}{*}{ Arenig } \\
\hline & \multirow{2}{*}{ Latorp $\mathrm{B}_{1}$} & \multirow{2}{*}{$\mathrm{U}$} & extensus & \\
\hline & & & approximatus & \\
\hline & \multicolumn{2}{|l|}{ Varangu $A_{111}$} & & \multirow[t]{2}{*}{ Tremadoc } \\
\hline & \multicolumn{2}{|l|}{ Pakerort $A_{11}$} & flabelliformis & \\
\hline
\end{tabular}


The regional standard of the chart consists of three Baltoscandian series (accepted by the Stratigraphic Committee in 1985 officially as «superstages»): Oelandian, Viruan and Harjuan. The lower boundary of Viru Series is drawn at the base of the murchisoni Zone (Алихова, 1960; Jaanusson, 1960), that of Harju Series tentatively at the base of the Nabala Stage. 18 regional stages are accepted, most of them being welldefined Fr. Schmidt's traditional units with refinements proposed by several authors (Orviku, 1940; Jaanusson, 1944; and others). Seven of the stages are subdivided into two or three regional substages which results in total of 27 formal chronostratigraphic subdivisions of the system in the given region.

In separate columns biostratigraphic information on graptolites, conodonts, chitinozoans, trilobites, brachiopods, ostracodes, and various fossils is given.

The right side of the chart consists of 10 columns according to the accepted number of different stratigraphic districts. The division of the region into districts is provisional and based on different criteria. In some cases it reflects really existing sedimentary and faunal differences (facies resp. confacies belts), in other instances the division means only isolated or surface and subsurface occurrences of Ordovician rocks. By means of different columns a correlation in total of about 200 formal lithostratigraphic units, including 125 named formations and groups is given. Most of them are subsurface units and their correlation accepted in the chart, especially of those of late Viruan and Harjuan age, is still provisional. The correlation between the North Estonian type area, the Central Confacies Belt and Moscow Basin subsurface needs further investigation.

\section{REFERENCES}

Jaanusson, V. Ubersicht der Stratigraphie der Lyckholm-Komplexstufe // Bull. Comm. Geol. Finlande, 1944, N 132, 92-100.

Jaanusson, V. Faunal dynamics in the Middle Ordovician (Viruan) of Balto-Scandia /I M. G. Bassett (ed.). The Ordovician System. Proc. Palaeont. Ass. Symp. Birmingham, 1974. Cardiff, 1976, 301-326.

Jaanusson, V. Graptoloids from the Ontikan and Viruan (Ordov.) Limestones of Estonia and Sweden // Upps. Univ. Geol. Inst. Bull., 1960, 38, 289-366.

Orviku, K. Lithologie der Tallinna-Serie (Ordovizium, Estland) // Tartu Ulikooli Geol. Inst. Toim., 1940, N 58.

Stratigraphic Code of the USSR. Leningrad, 1979.

Алихова T. Н. Стратиграфия ордовикских отложеннй Русской платформы. М., 1960.

Инструкция по составлению корреляционных стратиграфических схем для территории СССР и отдельных ее регионов. М., 1958.

Мянниль Р. М. Исторня развития Балтийского бассейна в ордовике. Таллин, 1966.

Решения межведомственного совещания по разработке унифнцированных стратиграфических схем верхнего докембрия и палеозоя Русской платформы, 1962 г. Л., $1965,20-25$.

Решения межведомственного регионального стратиграфического совещания по разработке унифицированных стратиграфнческих схем Прибалтикн 1976 г. с унифицированными стратиграфическими корреляционными таблицами. Л., 1978, $48-56$.

Решения межведомственного стратиграфического совещания по ордовику и силуру Восточно-Европейской платформы 1984 г. с региональными стратиграфнческими схемами. Л., 1987, 17-57.

Academy of Sciences of the Estonian SSR, Institute of Geology 


\section{IDA-EUROOPA PLATVORMI NSV LIIDU-OSA ORDOVIITSIUMI KORRELATSIOONISKEEMIDEST}

Geoloogilise kaardistamise detailsemaks muutumine on tinginud vajaduse täiustada stratigraafilisi ja korrelatsiooniskeeme. Artiklis on esitatud ülevaade Ida-Euroopa platvormi ordoviitsiumi seni koostatud ametlikest skeemidest: esimene, nn. Vene platvormi skeem ilmus 1965, Baltikumi skeem 1978, Valgevene skeem 1983 ja uus Ida-Euroopa platvormi skeem 1987. Viimases kasutatud üldised ja regionaalsed stratoonid on esitatud tabelina.

\section{Р. МЯнНиль}

\section{О КОРРЕЛЯЦИОННЫХ СТРАТИГРАФИЧЕСКИХ СХЕМАХ ОРДОВИКА ВОСТОЧНО-ЕВРОПЕИСКОИ ПЛАТФОРМЫ В ПРЕДЕЛАХ СССР}

Увеличение детальности геологического картирования обусловило необходимость усовершенствования стратиграфических и корреляционных схем. В статье приводится обзор официальных схем ордовика платформы, составленных до сих пор - первая т. н. схема Русской платформы издана в 1965 г., схема Прибалтики в 1978 г., схема Белоруссии в 1983 г. и новая схема Восточно-Европейской платформы в 1987 г. Общие и региональные стратоны из последней схемы представлены в виде таблицы.

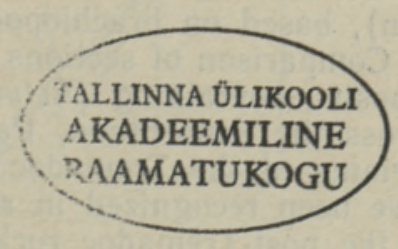

